\title{
Association between birth weight and educational attainment : an individual-based pooled analysis of nine twin cohorts
}

\author{
Jelenkovic, Aline
}

2018-09

Jelenkovic , A, Mikkonen , J , Martikainen, P , Latvala , A, Yokoyama , Y, Sund , R , Vuoksimaa , E, Rebato , E , Sung , J , Kim , J , Lee , J , Lee , S , Stazi , M A, Fagnani , C , Brescianini , S, Derom , C A, Vlietinck, R F , Loos, R J F, Krueger , R F , Mcgue , M , Pahlen , S , Nelson , T L , Whitfield , K E , Brandt , I, Nilsen , T S , Harris , J R , Cutler , T L , Hopper , J L , Tarnoki , A D , Tarnoki , D L , Sorensen , T I A , Kaprio , J \& Silventoinen , K 2018 , ' Association between birth weight and educational attainment : an individual-based pooled analysis of nine twin cohorts ' , Journal of Epidemiology \& Community Health , vol. 72 , no. 9 , pp. 832-837 . https://doi.org/10.1136/jech-2017-210403

cc_by_nc

acceptedVersion

Downloaded from Helda, University of Helsinki institutional repository.

This is an electronic reprint of the original article.

This reprint may differ from the original in pagination and typographic detail.

Please cite the original version. 
Association between birth weight and educational attainment: An individual-based pooled analysis of nine twin cohorts

Aline Jelenkovic (1) (2), Janne Mikkonen (1), Pekka Martikainen (1), Antti Latvala (3), Yoshie Yokoyama (4), Reijo Sund (1) (5), Eero Vuoksimaa (3), Esther Rebato (2), Joohon Sung (6) (7), Jina Kim (6), Jooyeon Lee (6), Sooji Lee (6), Maria A Stazi (8), Corrado Fagnani (8), Sonia Brescianini (8), Catherine A Derom (9) (10), Robert F Vlietinck (9), Ruth JF Loos (11), Robert F Krueger (12), Matt McGue (12), Shandell Pahlen (12), Tracy L Nelson (13), Keith E Whitfield (14), Ingunn Brandt (15), Thomas S Nilsen (15), Jennifer R Harris (15), Tessa L Cutler (16), John L Hopper (16) (6), Adam D Tarnoki (17) (18), David L Tarnoki (17) (18), Thorkild IA Sørensen (19) (20), Jaakko Kaprio (21) (3), Karri Silventoinen (1) (22)

1. Department of Social Research, University of Helsinki, Helsinki, Finland.

2. Department of Genetics, Physical Anthropology and Animal Physiology, University of the Basque Country UPV/EHU, Leioa, Spain.

3. Institute for Molecular Medicine Finland, University of Helsinki, Helsinki, Finland.

4. Department of Public Health Nursing, Osaka City University, Osaka, Japan.

5. Institute of Clinical Medicine, University of Eastern Finland, Kuopio, Finland.

6. Department of Epidemiology, School of Public Health, Seoul National University, Seoul, Korea.

7. Institute of Health and Environment, Seoul National University, Seoul, South-Korea.

8. Istituto Superiore di Sanità - Centre for Behavioural Sciences and Mental Health, Rome, Italy.

9. Centre of Human Genetics, University Hospitals Leuven, Leuven, Belgium.

10. Department of Obstetrics and Gynaecology, Ghent University Hospitals, Ghent, Belgium.

11. The Charles Bronfman Institute for Personalized Medicine, The Mindich Child Health and

Development Institute, Icahn School of Medicine at Mount Sinai, New York, NY, USA.

12. Department of Psychology, University of Minnesota, Minneapolis, MN, USA.

13. Department of Health and Exercise Sciencies and Colorado School of Public Health, Colorado State University, USA.

14. Psychology and Neuroscience, Duke University, Durham, NC, USA.

15. Norwegian Institute of Public Health, Oslo, Norway.

16. The Australian Twin Registry, Centre for Epidemiology and Biostatistics, The University of Melbourne, Melbourne, Victoria, Australia.

17. Department of Radiology, Semmelweis University, Budapest, Hungary.

18. Hungarian Twin Registry, Budapest, Hungary.

19. Novo Nordisk Foundation Centre for Basic Metabolic Research (Section of Metabolic Genetics), Faculty of Health and Medical Sciences, University of Copenhagen, Copenhagen, Denmark.

20. Department of Public Health (Section of Epidemiology), Faculty of Health and Medical Sciences, University of Copenhagen, Copenhagen, Denmark.

21. Department of Public Health, University of Helsinki, Helsinki, Finland.

22. Osaka University Graduate School of Medicine, Osaka University, Osaka, Japan.

Correspondence to: Aline Jelenkovic. Population Research Unit, Department of Social Research, University of Helsinki, Helsinki 00014 (P.O. Box 18), Finland. Tel: +358 2941 911. Fax: +358 9 191 23967.email: aline.jelenkovic@ helsinki.fi 


\begin{abstract}
Background: There is evidence that birth weight is positively associated with education, but it remains unclear whether this association is explained by familial environmental factors, genetic factors or the intrauterine environment. We analyzed the association between birth weight and educational years within twin pairs, which controls for genetic factors and the environment shared between co-twins.
\end{abstract}

Methods: The data were derived from nine twin cohorts in eight countries including 6116 complete twin pairs. The association between birthweight and educational attainment was analyzed both between individuals and within pairs using linear regression analyses.

Results: In between-individual analyses, birth weight was not associated with educational years. Within-pairs analyses revealed positive but modest associations for some sex, zygosity and birth year groups. The greatest association was found in DZ men (0.65 educational years $/ \mathrm{kg}$ birth weight, $P=0.006$ ); smaller effects of 0.3 educational years $/ \mathrm{kg}$ birth weight were found within monozygotic (MZ) twins of both sexes and opposite-sex dizygotic (DZ) twins. The magnitude of the associations differed by birth year in MZ women and opposite-sex DZ twins, showing a positive association in the 1915-1959 birth cohort but no association in the 1960-1984 birth cohort.

Conclusion: Although associations are weak and somewhat inconsistent, our results suggest that intrauterine environment may play a role when explaining the association between birth weight and educational attainment.

\title{
Keywords
}

Birth weight, education, twins 
What is already known on this subject?

-There is evidence that birth weight is positively associated with education.

-It remains unclear whether the association is explained by familial environmental factors, genetic factors or the intrauterine environment, or whether it differs by sex or has changed over time.

What does this study add?

-In this sample of nine twin cohorts from eight countries, birth weight was positively but modestly related to educational attainment within twin pairs, although the associations varied by sex, zygosity and birth year groups.

-The association between birth weight and educational attainment diminished in more recent cohorts, particularly in women.

-The associations within monozygotic pairs suggest that intrauterine environment may play a role when explaining the association between birth weight and educational attainment. 
Education is one of the most important dimensions of socio-economic status in modern societies [1] and an important determinant of health [2]. The long-lasting influence of birth size on education has been widely discussed, but the evidence remains mixed. Lower birth weight has been associated with lower education (measured as educational years, high school graduation, or school test scores at different ages) [3-6]; however, some studies did not find any association [7-9]. Studies of siblings controlling for shared maternal and family factors support the positive associations [10-12], but do not clarify whether the association is explained by genetic or individual-specific environmental factors. A very modest and non-significant genetic correlation $(\sim 0.096)$ between birth weight and educational years was obtained from genome-wide association study (GWAS) summary statistics [13]. A recent study using genetic variants and twin status as an instrumental variable reported no causal effect of birth weight on either educational attainment or academic performance, and suggested that the small positive associations observed using conventional epidemiologic methods are likely due to residual confounding by maternal, social and contextual environmental attributes existing already before birth [14].

The twin design offers an opportunity to shed light on the mechanisms underlying the association between birth weight and education [15]. Differences in birth weight and education within monozygotic (MZ) pairs can only be influenced by environmental factors that are unique to individuals (e.g. different vascularization of the placenta [16]), thus suggesting that the intrauterine environment has a role in driving the association between birth weight and education. Differences within dizygotic (DZ) pairs can also be influenced by genetic factors; a stronger association within DZ than MZ twin pairs is taken as evidence of the role of genetic factors [15]. Within twin pairs, birth weight has generally shown a positive association with educational performance in childhood [17] and adolescence [18,19], as well as with the probability of high school completion [20]. For the highest educational years measured in adulthood, both modest positive [21-23] and non-significant 
effects $[19,24,25]$ have been reported. However, these studies used different criteria to select twin pairs (only MZ or all same-sex twins together (MZ and DZ)), and none of them provided estimates separately in MZ and DZ twins. Furthermore, since boys are born heavier than girls [26,27], and mean education level may have increased more rapidly over time in women than in men because of the lower accessibility for women to higher education decades ago [28], the association between birth weight and education may differ by sex or have changed over time. Finally, it is possible that publication bias may have promoted the reporting of positive results [29]. To address these questions, we analyzed the association between birth weight and educational attainment separately in MZ and DZ twins of both sexes born in 1915-1984 in multinational data from nine twin cohorts.

\section{Methods}

\section{Sample}

This study is based on the data from the COllaborative project of Development of Anthropometrical measures in Twins (CODATwins), which was intended to pool data from all twin projects in the world having information on height and weight [30]. Additional information on birth weight and education was available for nine twin cohorts from eight countries. The participating twin cohorts are identified in Table 1 (footnote) and were previously described in detail [30,31].

In the original database, there were 17,499 twin individuals with information on birth weight and education from ages 30 to 82 years. We restricted the analyses to individuals aged $\geq 30$ years because they are likely to have completed their education. We excluded individuals with birth weight $<0.5$ or $>5 \mathrm{~kg}(\mathrm{n}=6)$, with 0 years of education $(\mathrm{n}=1)$, or without data on their co-twins ( $\mathrm{n}=5208)$ resulting in 6142 twin pairs. Intra-pair differences in birth weight were checked by visual inspection of histograms and 26 twin pairs with differences $>1.7 \mathrm{~kg}$ were removed. Taken together, 
we had 6116 complete twin pairs (48\% MZ and 34\% same-sex DZ and 18\% opposite-sex DZ), of which 1757 are formed by both co-twins of low birth weight $(<2.5 \mathrm{~kg})$. Birth weight was mostly self-reported $(75.6 \%)$ or parental-reported $(22.8 \%)$; only $1.6 \%$ of the sample was based on medical records of birth weights. The different educational classifications used in the original surveys were transformed to educational years by using the mean level of educational years in each category (Supplementary Table 1).

All participants were volunteers and gave informed consent when participating in their original studies. Only a limited set of observational variables and anonymized data were delivered to the data management center at the University of Helsinki. The pooled analysis was approved by the ethical committee of the Department of Public Health, University of Helsinki.

\section{Statistical analyses}

Statistical analyses were conducted using Stata (version 12.0; StataCorp, College Station, Texas, USA). In the between-individual analyses (twins treated as individuals), linear regression models for each sex and zygosity group (including opposite-sex DZ twins) were used with birth weight as the explanatory variable and educational years as the outcome variable. The associations were adjusted for birth year, quadratic term of birth year and twin cohort; the quadratic term of birth year was significant in some associations and thus systematically introduced in all regression models. The non-independence within twin pairs was taken into account by using the cluster option of Stata. For the within-pair analyses, intra-pair differences in birth weight were calculated by randomly subtracting the twin with the smallest birth weight from the co-twin with the largest birth weight or vice versa; the twin order was the same for the calculation of intra-pair differences in educational years (birth weight and educational years were first adjusted for sex in opposite-sex DZ twins). This guarantees an approximately normal distribution of the new variables. We then performed linear 
regression models for each sex and zygosity group with intra-pair birth weight difference as the explanatory variable and intra-pair difference in educational years as the outcome variable. The associations were also adjusted for birth year, quadratic term of birth year and twin cohort. Pooled

analyses of twin cohorts was justified by the low and statistically non-significant $\left(\mathrm{I}^{2}=30 \%, \mathrm{p}=0.178\right)$ heterogeneity in the birth weight-education association between cohorts based on a random effects meta-regression model [32] (Supplementary Figure 1).

An interaction analysis was performed to investigate whether zygosity influenced the associations between birth weight and education by introducing a product term of zygosity and birth weight (between-individual analyses) or intra-pair birth weight differences (within-pair analyses) into the regression model. Further, regression models were 1) additionally adjusted for height (betweenindividual analyses) or intra-pair height difference (within-pair analyses); 2) carried out separately in two birth year cohorts (1915-1959 and 1960-1984; 1960); and 3) restricted to twin pairs of low birth weight $(2.5 \mathrm{~kg})$. The birth year 1960 cut-off point was based on the sample size and related health and social changes in overall development contexts (e.g. deliveries at hospitals became more common, decreasing infant mortality and increasing survival of twins, and access to higher education easier for those individuals born in the 1960s or later).

\section{Results}

Mean birth weight was slightly greater in men than in women and in DZ than in MZ twins but similar in the two birth year cohorts (Table 1). Mean years of education was somewhat greater in men than in women, in MZ than in DZ twins, and in the 1960-1984 birth cohort than in the 19151959; the difference between birth year cohorts was greater in women than in men. 
In the between-individual analyses, birth weight was generally not associated with educational attainment (Table 2). The only significant association was found for DZ women born in 1960-1984, with 0.33 years longer education per $1 \mathrm{~kg}$ increase in birth weight. In an additional regression model with birth weight categorized (footnote b, Table 2), there was some evidence on non-linearity since the point estimates were lower both in the lowest and highest categories of birth weight than in the middle category; the differences were, however, not statistically significant. Within twin pairs, the greatest association was observed for DZ men (0.65 educational years/kg birth weight), whereas in DZ women the association was not significant (-0.13 educational years/kg birth weight). In MZ women, a $1 \mathrm{~kg}$ increase in birth weight was related to an increase of 0.31 educational years; a very similar association was observed in MZ men (0.32 educational years/kg birth weight) and oppositesex DZ twins (0.38 educational years/kg birth weight) but was not significant.

The interaction term between zygosity and birth weight/intra-pair birth weight difference was significant only within pairs in women $(P=0.027)$. Adjustment for height/ intra-pair height differences did not change the magnitude of the associations. The greatest differences between birth year cohorts were observed within pairs in MZ women and opposite-sex DZ twins, showing a positive association in the 1915-1959 cohort, but no association in the 1960-1984 cohort. Restricting the analyses to twin pairs of low birth weight $(2.5 \mathrm{~kg})$ did not show any clear trend. Sensitivity analyses removing individuals with birth weight $<1.5 \mathrm{~kg}$ or $<2.5 \mathrm{~kg}$ did not reveal additional information (results not shown).

\section{Discussion}

In the present study of 6116 twin pairs from eight countries, birth weight was not related to educational attainment between individuals but showed a modest positive association within twin pairs in some sex, zygosity and birth year groups. The magnitude of these associations is generally 
similar to that found in previous studies: $\sim 0.7$ educational years $/ \mathrm{kg}$ birth weight in twins from Minnesota -Minnesota Twin Registry was also included in the present study- [21], and $\sim 0.2$ educational years/kg birth weight in twins from California [22] and Taiwan [23]. In Japanese twins, birth weight was associated with academic performance (grades) at $\sim 15$ years of age but not with the highest years of education, suggesting that the effects are larger at younger than at older ages [19]. In the CODATwins database, we do not have information on the academic performance at school; so we do not know whether the difference in achieved educational years is because of better school performance or because of continuing education with lower grades. Regarding birth year, the most remarkable difference observed in MZ women and opposite-sex DZ pairs suggests that the association between birth weight and education disappears in more recent birth cohorts. This may be the result of improving pre- and postnatal care of twin pregnancies or changes in parenting/school systems. Lin and Liu [33] found that birth weight was positively associated with school grades only when both twins weigh less than $3 \mathrm{~kg}$ at birth in a Taiwanese sample, a finding that was not replicated in our study when restricting the analyses to low birth weight twin pairs.

None of the previous studies [17-25] reported within-pair associations between birth weight and education in childhood or adulthood in both MZ and DZ twins. Although the association was somewhat greater within DZ than within MZ pairs in men, the lack of interaction between zygosity and intra-pair birth weight differences indicated that the associations in DZ twins and MZ twins were not significantly different, and thus the role of genetic factors remains uncertain. Because the associations were observed within MZ twins, at least in women, our results support the role of environmental factors unique to each individual behind the association, which is in agreement with the findings in $\mathrm{MZ}$ women from Minnesota [21]. Since MZ twins can differ in their prenatal environment [34], the observed associations suggest that educational differences have roots already in fetal life. Birth weight has been associated with cognition through childhood, adolescence and 
early adulthood [20,35-37], and a Dutch twin study suggested that genetic factors mediate part of the association between birth weight and childhood IQ [38]. Cross-trait LD Score regression of GWAS data showed genetic correlations of $0.096(\mathrm{SE}=0.064, \mathrm{p}=0.131)$ between birth weight and education years and of $0.141(\mathrm{SE}=0.124, \mathrm{p}=0.257)$ between birth weight and childhood IQ, indicating at most modest (and non-significant) shared genetic effects [13]. Therefore, it is possible that the link between birth weight and educational attainment is mediated, at least in part, by brain development. In the literature, low birth weight has been related to adverse outcomes, such as poorer health status [39] and the presence of mild neurological deficits [40], which may impair ability to attend school even in the absence of cognitive limitations. Moreover, behavioural factors might also play a role in the association between birth weight and educational attainment; previous twin studies have suggested a causal association of lower birth weight with child problem behavior [41] and more specifically with internalizing problems and emotional reactiveness [42], which are strongly associated with poor educational attainment. Regarding other explanations than the the direct influence of prenatal environmental factors, it is possible that differential parental interaction in postnatal life has a role: a greater parental care to the heavier twin may lead to better education, but there is no reason to think that this would be specific for MZ twins.

The stronger associations of the within-pair design are in line with previous studies showing a stronger effect within twins [21] and among siblings [10] than across individuals of different families. However, although birth weight has generally been associated with education in singletons, we did not find clear association between twin individuals. It is well recognized that twin pregnancies are characterized by lower birth weight compared to singleton pregnancies and that intrauterine growth in twins, which may be particularly compromised in MZ twins, is different from that in singletons [43], but in recent birth cohorts educational achievement is similar in twins and singletons $[18,44]$. Therefore, there might be some twin pregnancy specific factors (e.g. 
mother's capability to adapt to twin pregnancy) affecting birth weight (but not education) that would be causing extra variation between twin pregnancies thus concealing the co-variation between birth weight and education between twin individuals. If factors affecting differences between co-twins, such as nutrition due to different vascularization, are also associated with education, they may become apparent in within-pair analyses because factors associated with the mother are adjusted for. Therefore, even if differences between twin individuals are not representative of the general population because of the extra variation between pregnancies, we can speculate that the same factors creating differences between co-twins also create differences between singletons.

The main strength of the present study is the large sample size with information on birth weight and educational years in MZ and DZ twins of both sexes. However, our data do not include information on singletons, and thus we cannot study whether the relationship between birth weight and education in twins differ from singletons. Another limitation of the data is that most of the birth weight measures were self- or parental reported. However, the accuracy between maternal recall and medical records of birth weights has shown to be very high both in singletons $[45,46]$ and twins [47]. The marker of education years has the advantage that it is more easily comparable across studies, but it does not clarify the attained educational category. Moreover, pooling data from twin cohorts representing different countries and birth cohorts creates challenges when harmonizing educational classifications; by adjusting educational years for twin cohort and birth year, we thus focussed on relative rather than absolute education.

In conclusion, although the association is modest and somewhat differs by sex, zygosity and birth year, birth weight is positively associated with educational attainment within twin pairs. Our findings suggest that intrauterine environment may play a role when explaining the association between birth weight and educational attainment. 


\section{Acknowledgements}

This work was supported by the Academy of Finland (grant \#266592). The Australian Twin Registry is supported by a Centre of Research Excellence (grant ID 1079102) from the National Health and Medical Research Council administered by the University of Melbourne. The Carolina African American Twin Study of Aging (CAATSA) was funded by a grant from the National Institute on Aging (grant 1RO1-AG13662-01A2) to K. E. Whitfield. Since its origin the East Flanders Prospective Survey has been partly supported by grants from the Fund of Scientific Research, Flanders and Twins, a non-profit Association for Scientific Research in Multiple Births (Belgium). Data collection and analyses in Finnish twin cohorts have been supported by ENGAGE - European Network for Genetic and Genomic Epidemiology, FP7-HEALTH-F4-2007, grant agreement number 201413, National Institute of Alcohol Abuse and Alcoholism (grants AA-12502, AA-00145, and AA-09203 to R J Rose, the Academy of Finland Center of Excellence in Complex

Disease Genetics (grant numbers: 213506, 129680), and the Academy of Finland (grants 100499, 205585, 118555, 141054, 265240, 263278 and 264146 to J Kaprio). Anthropometric measurements of the Hungarian twins were supported by Medexpert Ltd., Budapest, Hungary. Korean TwinFamily Register was supported by the Global Research Network Program of the National Research Foundation (NRF 2011-220-E00006).

\section{Licence for Publication}

The Corresponding Author has the right to grant on behalf of all authors and does grant on behalf of all authors, an exclusive licence (or non exclusive for government employees) on a worldwide basis to the BMJ Publishing Group Ltd to permit this article (if accepted) to be published in JECH and 
any other BMJPGL products and sublicences such use and exploit all subsidiary rights, as set out in our licence (http://group.bmj.com/products/journals/instructions-for-authors/licence-forms).

\section{Competing Interest}

None declared

\section{Contributorship Statement}

YY, TIAS, JK and KS planned the study design of the CODATwins project. YY, JS, JK, JL, SL, MAS, CF, SB, CAD, RFV, RFJL, RFK, MM, SP, TLN, KEW, IB, TSN, JRH, TLC, JLH, ADT, DLT and JK collected the data used in this study. AJ and KS were in charge of data management. RS provided statistical advice. AJ conducted the analyses and wrote the first draft of the manuscript. All authors have commented the manuscript and read and approved the final version of the manuscript.

\section{References}

1 Hout M, DiPrete TA. What we have learned: RC28's contributions to knowledge about social stratification. Res Soc Stratif Mobil 2006;24:1-20.

2 Mackenbach JP, Stirbu I, Roskam AJ, et al. Socioeconomic inequalities in health in 22 European countries. N Eng J Med 2008;358:2468-2481.

3 Breslau N, Paneth NS, Lucia VC. The lingering academic deficits of low birth weight children. Pediatrics 2004;114:1035-1040.

4 Chatterji P, Kim D, Lahiri K. Birth weight and academic achievement in childhood. Health Econ 2014;23:1013-1035. 
5 Litt JS, Gerry Taylor H, Margevicius S, et al. Academic achievement of adolescents born with extremely low birth weight. Acta Paediatr 2012;101:1240-1245.

6 Lefebvre F, Mazurier E, Tessier R. Cognitive and educational outcomes in early adulthood for infants weighing 1000 grams or less at birth. Acta Paediatr 2005;94:733-740.

7 Harkonen J, Kaymakcalan H, Maki P, et al. Prenatal health, educational attainment, and intergenerational inequality: the Northern Finland Birth Cohort 1966 Study. Demography 2012;49:525-552.

8 Strauss RS. Adult functional outcome of those born small for gestational age: twenty-six-year follow-up of the 1970 British Birth Cohort. JAMA 2000;283:625-632.

9 Saigal S, Stoskopf B, Streiner D, et al. Transition of extremely low-birth-weight infants from adolescence to young adulthood: comparison with normal birth-weight controls. JAMA 2006;295:667-675.

10 Conley D, Bennett NG. Is biology destiny? Birth weight and life chances. Am Sociol Rev 2000;65:458-467.

11 Johnson RC, Schoeni RF. The influence of early-life events on human capital, health status, and labor market outcomes over the life course. B E J Econom Anal Policy 2011;11:2521.

12 Fletcher JM. The medium term schooling and health effects of low birth weight: Evidence from siblings. Econ Educ Rev 2011;30:517-527.

13 Bulik-Sullivan B, Finucane HK, Anttila V, et al. An atlas of genetic correlations across human diseases and traits. Nat Genet 2015;47:1236-1241. 
14 Lin SL, Leung GM, Schooling CM. The effect of birth weight on academic performance: instrumental variable analysis. Am J Epidemiol 2017;185:853-859.

15 Boomsma D, Willemsen G, Geus E, Kupper N, Posthuma D, IJzerman R, et al. Twins and the fetal origins hypothesis: An application to growth data. Hormones and the Brain Heidelberg: Springer-Verlag Berlin; 2005:29-46.

16 Derom R, Derom C, Vlietinck R. Placentation. In: Blickstein I, Keith LG, eds. Multiple Pregnancy. Second ed. London and New York: Taylor \& Francis; 2005:157-167.

17 Asbury K, Dunn JF, Plomin R. Birthweight-discordance and differences in early parenting relate to monozygotic twin differences in behaviour problems and academic achievement at age 7. Dev Sci 2006;9:F22-F31.

18 Christensen K, Petersen I, Skytthe A, et al. Comparison of academic performance of twins and singletons in adolescence: follow-up study. BMJ 2006;333:1095.

19 Nakamuro M, Uzuki Y, Inui T. The effects of birth weight: Does fetal origin really matter for long-run outcomes? Econ Lett 2013;121:53-58.

20 Black SE, Devereux PJ, Salvanes K. From the cradle to the labor market? The effect of birth weight on adult outcomes. Q J Econ 2007;122:409-439.

21 Behrman JR, Rosenzweig MR. Returns to birthweight. Rev Econ Stat 2004;86:586-601.

22 Royer H. Separated at girth: US twin estimates of the effects of birth weight. Am Econ J: Applied Economics 2009;1:49-85.

23 Xie ZX, Chou SY, Liu JT. The short-run and long-run effects of birth weight: Evidence from large samples of siblings and twins in Taiwan. Health Econ 2016;26:910-921. 
24 Miller P, Mulvey C, Martin N. Birth weight and schooling and earnings: estimates from a sample of twins. Econ Lett 2005;86:387-392.

25 Tsou MT, Tsou MW, Wu MP, et al. Academic achievement of twins and singletons in early adulthood: Taiwanese cohort study. BMJ 2008;337:a438.

26 Cogswell ME, Yip R. The influence of fetal and maternal factors on the distribution of birthweight. Semin Perinatol 1995;19:222-240.

27 Glinianaia SV, Skjaerven R, Magnus P. Birthweight percentiles by gestational age in multiple births. A population-based study of Norwegian twins and triplets. Acta Obstet Gynecol Scand 2000;79:450-458.

28 Diprete TA, Buchmann C. Gender-specific trends in the value of education and the emerging gender gap in college completion. Demography 2006;43:1-24.

29 Thornton A, Lee P. Publication bias in meta-analysis: its causes and consequences. J Clin Epidemiol 2000;53:207-216.

30 Silventoinen K, Jelenkovic A, Sund R, et al. The CODATwins Project: The cohort description of COllaborative Project of Development of Anthropometrical Measures in Twins to study macroenvironmental variation in genetic and environmental effects on anthropometric traits. Twin Res Hum Genet 2015;18:348-360.

31 Silventoinen K, Jelenkovic A, Latvala A, et al. Education in twins and their parents across birth cohorts over 100 years: An individual-level pooled analysis of 42 twin cohorts. Twin Res Hum Genet 2017;20:395-405. 
32 Higgins JP, Thompson SG, Deeks JJ, et al. Measuring inconsistency in meta-analyses. BMJ 2003;327:557-560.

33 Lin MJ, Liu JT. Do lower birth weight babies have lower grades? Twin fixed effect and instrumental variable method evidence from Taiwan. Soc Sci Med 2009;68:1780-1787.

34 Martin N, Boomsma D, Machin G. A twin-pronged attack on complex traits. Nat Genet 1997; 17:387-392.

35 Newcombe R, Milne BJ, Caspi A, et al. Birthweight predicts IQ: fact or artefact? Twin Res Hum Genet 2007;10:581-586.

36 Richards M, Hardy R, Kuh D, et al. Birth weight and cognitive function in the British 1946 birth cohort: longitudinal population based study. BMJ 2001;322:199-203.

37 Sorensen HT, Sabroe S, Olsen J, et al. Birth weight and cognitive function in young adult life: historical cohort study. BMJ 1997;315:401-403.

38 Boomsma DI, van Beijsterveldt CE, Rietveld MJ, et al. Genetics mediate relation of birth weight to childhood IQ. BMJ 2001;323:1426-1427.

39 Currie J. Healthy, wealthy, and wise: socioeconomic status, poor health in childhood, and human capital development. J Econ Lit 2009;47:87-122.

40 Aram DM, Hack M, Hawkins S, et al. Very-low-birthweight children and speech and language development. J Speech Hear Res 1991;34:1169-1179.

41 van Os J, Wichers M, Danckaerts M, et al. A prospective twin study of birth weight discordance and child problem behavior. Biol Psychiatry 2001;50:593-599. 
42 Tore EC, Antoniou EE, Reed K, et al. The association of intrapair birth-weight differences with internalizing and externalizing behavior problems. Twin Res Hum Genet 2018;:1-10.

43 Morley R. Can we generalise from findings in twins? Paediatr Perinat Epidemiol 2005;19

Suppl 1:54-59.

44 de Zeeuw EL, de Geus EJC, Boomsma DI. Meta-analysis of twin studies highlights the importance of genetic variation in primary school educational achievement. Trends in Neuroscience and Education 2015;4:69-76.

45 McCormick MC, Brooks-Gunn J. Concurrent child health status and maternal recall of events in infancy. Pediatrics 1999;104:1176-1181.

46 Jensen CB, Gamborg M, Heitmann B, et al. Comparison of birth weight between school health records and medical birth records in Denmark: determinants of discrepancies. BMJ Open 2015;5:e008628-2015-008628.

47 Pietiläinen K. Genetic and environmental influences on body image, disordered eating, and intentional weight loss 2004. 
Table 1. Descriptive statistics of birth weight and educational attainment by sex, zygosity and birth year

\begin{tabular}{|c|c|c|c|c|c|c|c|c|c|c|c|c|}
\hline & \multicolumn{6}{|l|}{ Men } & \multicolumn{6}{|l|}{ Women } \\
\hline & \multicolumn{3}{|l|}{$\mathrm{MZ}$} & \multicolumn{3}{|l|}{ DZ } & \multicolumn{3}{|l|}{$\mathrm{MZ}$} & \multicolumn{3}{|l|}{ DZ } \\
\hline & $\mathrm{N}$ & Mean & SD & $\mathrm{N}$ & Mean & SD & $\mathrm{N}$ & Mean & SD & $\mathrm{N}$ & Mean & SD \\
\hline \multicolumn{13}{|l|}{ Birth weight (kg) } \\
\hline All & 1980 & 2.60 & 0.56 & 2669 & 2.78 & 0.56 & 3866 & 2.46 & 0.54 & 3717 & 2.63 & 0.54 \\
\hline Birth year 1915-1959 & 1304 & 2.60 & 0.58 & 1681 & 2.78 & 0.58 & 2288 & 2.45 & 0.55 & 2465 & 2.63 & 0.54 \\
\hline Birth year 1960-1984 & 676 & 2.61 & 0.52 & 988 & 2.77 & 0.53 & 1578 & 2.48 & 0.51 & 1252 & 2.63 & 0.55 \\
\hline \multicolumn{13}{|l|}{ Education (years) } \\
\hline All & 1980 & 14.29 & 3.18 & 2669 & 13.94 & 2.99 & 3866 & 13.84 & 3.05 & 3717 & 13.64 & 2.91 \\
\hline Birth year 1915-1959 & 1304 & 14.05 & 3.17 & 1681 & 13.85 & 2.99 & 2288 & 12.94 & 2.91 & 2465 & 13.05 & 2.73 \\
\hline Birth year 1960-1984 & 676 & 14.75 & 3.16 & 988 & 14.09 & 2.99 & 1578 & 15.15 & 2.75 & 1252 & 14.80 & 2.90 \\
\hline
\end{tabular}

Names of the participating twin cohorts in this study: Australian Twin Registry, Carolina African American Twin Study of Aging, East Flanders Prospective Twin Survey, Finntwin16, Hungarian Twin Registry, Italian Twin Registry, Korean Twin-Family Register, Minnesota Twin Registry, and Norwegian Twin Registry.

MZ, monozygotic twins; DZ, dizygotic twins; N, number of individuals. 
Table 2. Regression coefficients for the association between birth weight and educational attainment in the between-individual (educational years per kg birth weight) and within-pair (intra-pair educational years difference per intra-pair kg birth weight difference) analyses.

\begin{tabular}{|c|c|c|c|c|c|c|c|c|c|c|c|c|c|c|c|c|c|c|c|c|}
\hline \multirow{5}{*}{ Between-individual analyses } & \multicolumn{8}{|l|}{ Men } & \multicolumn{8}{|c|}{ Women } & \multirow{2}{*}{\multicolumn{4}{|c|}{ Opposite-sex DZ }} \\
\hline & \multicolumn{4}{|l|}{$\mathrm{MZ}$} & \multicolumn{4}{|l|}{$\mathrm{DZ}$} & \multicolumn{8}{|c|}{$\mathrm{MZ}$} & & & & \\
\hline & \multirow[t]{2}{*}{$\mathrm{B}$} & \multirow[t]{2}{*}{$P$} & \multicolumn{2}{|c|}{$95 \% \mathrm{CIs}$} & \multirow[t]{2}{*}{$\mathrm{B}$} & \multirow[t]{2}{*}{$P$} & \multicolumn{2}{|c|}{$95 \% \mathrm{CIs}$} & \multirow{2}{*}{ B B } & \multirow[t]{2}{*}{$P$} & \multicolumn{2}{|c|}{$95 \%$ CIs } & \multicolumn{4}{|c|}{$95 \% \mathrm{CIs}$} & \multirow{2}{*}{ B } & \multirow[t]{2}{*}{$P$} & \multicolumn{2}{|c|}{$95 \% \mathrm{CIs}$} \\
\hline & & & & & & & & & & & & & & & & & & & & \\
\hline & 0.00 & 0.999 & -0.31 & 0.31 & 0.01 & 0.906 & -0.21 & 0.24 & 0.01 & 0.904 & -0.18 & 0.21 & 0.09 & 0.298 & -0.08 & 0.27 & & & & \\
\hline All adjusted for height ${ }^{\mathrm{a}}$ & -0.17 & 0.276 & -0.49 & 0.14 & -0.12 & 0.319 & -0.35 & 0.11 & -0.07 & 0.469 & -0.27 & 0.12 & -0.01 & 0.894 & -0.19 & 0.17 & & & & \\
\hline Birth year 1915-1959 & 0.09 & 0.630 & -0.29 & 0.48 & -0.03 & 0.858 & -0.31 & 0.26 & 0.14 & 0.249 & -0.10 & 0.38 & -0.05 & 0.636 & -0.27 & 0.17 & & & & \\
\hline Birth year 1960-1984 & -0.10 & 0.691 & -0.62 & 0.41 & 0.18 & 0.345 & -0.19 & 0.54 & -0.19 & 0.246 & -0.53 & 0.14 & 0.33 & 0.037 & 0.02 & 0.63 & & & & \\
\hline Birth weight $<2.5 \mathrm{~kg}$ & 0.46 & 0.295 & -0.41 & 1.34 & 0.35 & 0.432 & -0.53 & 1.23 & -0.21 & 0.373 & -0.67 & 0.25 & 0.40 & 0.145 & -0.14 & 0.93 & & & & \\
\hline Within-pair analyses & \multicolumn{2}{|c|}{$\mathrm{N}$ pairs $=990$} & & & \multicolumn{2}{|c|}{$\mathrm{N}$ pairs $=779$} & & & \multicolumn{2}{|c|}{ N pairs $=1993$} & & & \multicolumn{2}{|c|}{$\mathrm{N}$ pairs $=1303$} & & & \multicolumn{2}{|c|}{$\mathrm{N}$ pairs $=1111$} & & \\
\hline All & 0.32 & 0.075 & -0.03 & 0.68 & 0.65 & 0.006 & 0.19 & 1.12 & 0.31 & 0.007 & 0.09 & 0.54 & -0.13 & 0.449 & -0.46 & 0.20 & 0.38 & 0.070 & -0.03 & 0.79 \\
\hline All adjusted for intra-pair height dif. ${ }^{a}$ & 0.30 & 0.113 & -0.07 & 0.68 & 0.64 & 0.009 & 0.16 & 1.11 & 0.27 & 0.026 & 0.03 & 0.50 & -0.17 & 0.314 & -0.51 & 0.16 & 0.40 & 0.054 & -0.01 & 0.81 \\
\hline Birth year 1915-1959 & 0.39 & 0.061 & -0.02 & 0.81 & 0.74 & 0.007 & 0.20 & 1.27 & 0.44 & 0.001 & 0.17 & 0.72 & 0.00 & 0.986 & -0.37 & 0.38 & 0.64 & 0.009 & 0.16 & 1.12 \\
\hline Birth year 1960-1984 & 0.20 & 0.575 & -0.49 & 0.89 & 0.50 & 0.312 & -0.47 & 1.47 & 0.05 & 0.793 & -0.35 & 0.46 & -0.44 & 0.194 & -1.11 & 0.23 & 0.07 & 0.840 & -0.62 & 0.76 \\
\hline Birth weight $<2.5 \mathrm{~kg}$ & -0.28 & 0.485 & -1.09 & 0.52 & 1.24 & 0.155 & -0.47 & 2.96 & 0.29 & 0.228 & -0.18 & 0.75 & -0.13 & 0.781 & -1.02 & 0.76 & 1.21 & 0.111 & -0.28 & 2.70 \\
\hline
\end{tabular}

MZ, monozygotic twins; DZ, dizygotic twins; B, regression coefficient; $95 \%$ CIs, 95\% confidence intervals; $n$, number of pairs.

${ }^{a}$ In the between-individual analyses, regression coefficient of height was significant $(P<0.001)$ for the four sex and zygosity groups. In the within-pair analyses, regression coefficient of intra-pair height difference was significant only in opposite-sex DZ twins $(P=0.003)$.

${ }^{b}$ Regression coefficients (educational years/kg birth weight; 95\%CIs) from a regression model with birth weight categorized (reference category $2.5-<3.0 \mathrm{~kg}$ ) as the independent variable and educational years as the dependent variable, adjusted for birth year, quadratic term of birth year, twin cohort sex zygosity and the clustering of twin pairs: $0.5-<2.0 \mathrm{~kg}(-0.13 ;-0.31,0.06), 2.0-<2.5 \mathrm{~kg}(-0.06 ;-0.20,0.07), 3.0-<3.5 \mathrm{~kg}(-0.11 ;-$ $0.26,0.04)$ and 3.5-5.0 (-0.19;-0.46,0.08) than for $2.5-<3.0 \mathrm{~kg}$. 


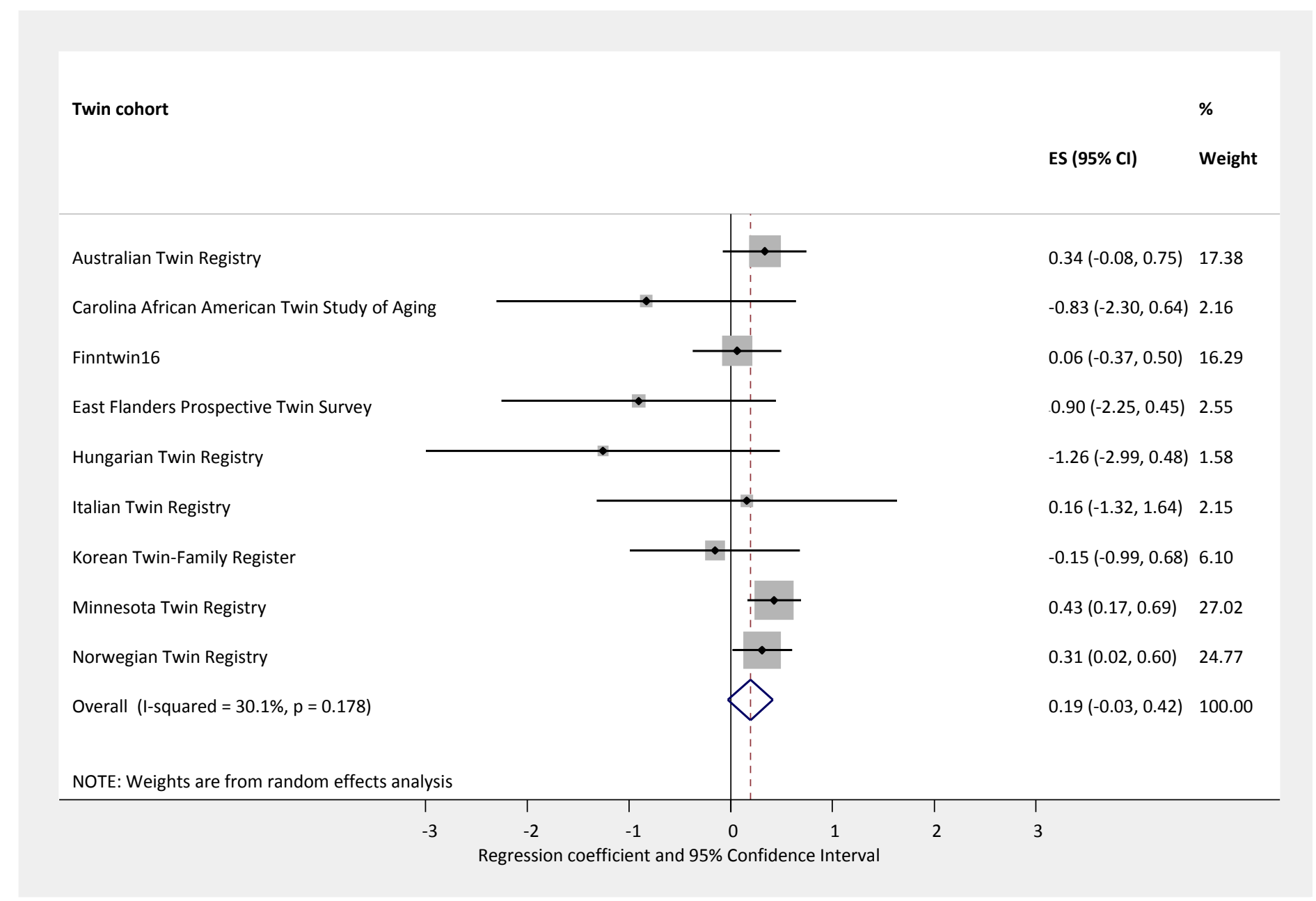

Supplementary Figure 1. Regression coefficient and 95\% CIs using a random-effects model with intra-pair education years difference as the dependent variable and intra-pair birth weight difference as the independent variable for twin pairs of the same sex (adjusted for birth year, the 
quadratic term of birth year, sex and zygosity). Squares indicate study-specific regression coefficients, and the size of the squares is proportional to the weight of each study, i.e., the inverse of the variance. The horizontal lines represent $95 \%$ CIs. To assess heterogeneity across cohorts, a random effects meta-regression model with inverse variance weighting derived from the DerSimonian and Laird estimator was performed using the user-written "metan" command in Stata and visualization of forest plots. The I2 statistic estimates the proportion of variation in effect sizes due to heterogeneity, whereby values of $25-49,50-74$, and $>75 \%$ indicate low, moderate, and high heterogeneity, respectively. 
Supplementary Table 1 . Number of education years in the harmonized variable, original classifications of education in the nine twin cohorts, and number of twin individuals by education categories.

\begin{tabular}{|c|c|c|c|c|c|c|}
\hline $\begin{array}{l}\mathrm{N} \text { of education } \\
\text { years } \\
\text { (harmonized) }\end{array}$ & $\begin{array}{l}\text { Australian Twin } \\
\text { Registry }\end{array}$ & n & $\begin{array}{l}\text { Carolina African } \\
\text { American Twin } \\
\text { Study of Aging }{ }^{1}\end{array}$ & $\mathbf{n}$ & $\begin{array}{l}\text { East Flanders } \\
\text { Prospective Twin } \\
\text { Survey }\end{array}$ & n \\
\hline 0 & & & & & & \\
\hline 1 & & & & & & \\
\hline 2 & & & & & & \\
\hline 3 & & & & & No diploma & - \\
\hline 4 & $\begin{array}{l}\text { Did not go to } \\
\text { school }\end{array}$ & - & & & & \\
\hline 5 & & & & & & \\
\hline 6 & & & & & $\begin{array}{l}\text { Primary education or } \\
\text { special primary } \\
\text { education }\end{array}$ & 2 \\
\hline 7 & & & & & & \\
\hline 8 & 8 years or below & 8 & & & & \\
\hline 9 & $\begin{array}{l}9 \text { years or } \\
\text { equivalent }\end{array}$ & 30 & 9 years or less & 1 & $\begin{array}{l}\text { Special secondary } \\
\text { education or lower } \\
\text { secondary general or } \\
\text { lower secondary } \\
\text { technical }\end{array}$ & 10 \\
\hline 10 & $\begin{array}{l}10 \text { years or } \\
\text { equivalent }\end{array}$ & 101 & 10 years & 4 & & \\
\hline 11 & $\begin{array}{l}11 \text { years or } \\
\text { equivalent }\end{array}$ & 46 & 11 years & 5 & & \\
\hline 12 & $\begin{array}{l}12 \text { years or } \\
\text { equivalent }\end{array}$ & 100 & 12 years & 36 & $\begin{array}{l}\text { Lower secondary } \\
\text { professionals or } \\
\text { higher secondary } \\
\text { general or higher } \\
\text { secondary technical } \\
\text { or higher secondary } \\
\text { professionals }\end{array}$ & 100 \\
\hline 13 & $\begin{array}{l}\text { VET certificate I } \\
\text { or II }\end{array}$ & 39 & 13 years & 5 & & \\
\hline 14 & $\begin{array}{l}\text { VET certificate } \\
\text { III or IV or trade } \\
\text { certificate }\end{array}$ & 126 & 14 years & 19 & $\begin{array}{l}\text { Non-university } \\
\text { higher education: } \\
\text { short type }\end{array}$ & 46 \\
\hline 15 & $\begin{array}{l}\text { VET Diploma or } \\
\text { advanced } \\
\text { diploma }\end{array}$ & 115 & 15 years & 5 & & \\
\hline 16 & Bachelor degree & 303 & 16 years & 22 & $\begin{array}{l}\text { Non-university } \\
\text { higher education: } \\
\text { long type }\end{array}$ & 16 \\
\hline 17 & $\begin{array}{l}\text { Graduate } \\
\text { diploma or } \\
\text { graduate } \\
\text { certificate }\end{array}$ & 268 & 17 years & 2 & & \\
\hline 18 & $\begin{array}{l}\text { Postgraduate } \\
\text { degree (masters / } \\
\text { PhD) }\end{array}$ & 176 & 18 years & 11 & $\begin{array}{l}\text { University and post- } \\
\text { university }\end{array}$ & 14 \\
\hline 19 & & & 19 years & 2 & & \\
\hline 20 & & & 20 years & 4 & & \\
\hline 21 & & & & & & \\
\hline
\end{tabular}


Supplementary Table 1 (continued).

\begin{tabular}{|c|c|c|c|c|c|c|}
\hline $\begin{array}{l}\mathrm{N} \text { of educational } \\
\text { years } \\
\text { (harmonized) }\end{array}$ & Finntwin16 & $\mathbf{n}$ & $\begin{array}{l}\text { Hungarian } \\
\text { Twin Registry }\end{array}$ & $\mathbf{n}$ & $\begin{array}{l}\text { Italian Twin } \\
\text { Registry }\end{array}$ & $\mathbf{n}$ \\
\hline 0 & & & & & None & \\
\hline 1 & & & & & & \\
\hline 2 & & & & & & \\
\hline 3 & & & & & & \\
\hline 4 & & & & & & \\
\hline 5 & & & & & $\begin{array}{l}\text { Elementary School (5 } \\
\text { years) }\end{array}$ & 8 \\
\hline 6 & & & $\begin{array}{l}\text { Less than } 8 \text { years } \\
\text { (below lower } \\
\text { secondary, no } \\
\text { vocational } \\
\text { education) }\end{array}$ & 2 & & \\
\hline 7 & & & & & & \\
\hline 8 & & & & & $\begin{array}{l}\text { Middle School (3 } \\
\text { years) }\end{array}$ & 33 \\
\hline 9 & Primary School & 57 & $\begin{array}{l}9-10 \text { years } \\
\text { (lower } \\
\text { secondary, no } \\
\text { vocational } \\
\text { education) }\end{array}$ & 23 & & \\
\hline 10 & & & & & & \\
\hline 11 & $\begin{array}{l}\text { Vocational } \\
\text { School }\end{array}$ & 568 & $\begin{array}{l}\text { 11-12 years } \\
\text { (lower secondary } \\
\text { plus vocational } \\
\text { school) } \\
\end{array}$ & 45 & & \\
\hline 12 & $\begin{array}{l}\text { Community } \\
\text { College degree or } \\
\text { matriculation } \\
\text { examination } \\
\end{array}$ & 597 & & & & \\
\hline 13 & & & & & High School (5 years) & 101 \\
\hline 14 & & & $\begin{array}{l}\text { 13-16 years } \\
\text { (upper } \\
\text { secondary, } \\
\text { vocational } \\
\text { college) }\end{array}$ & 28 & & \\
\hline 15 & & & & & & \\
\hline 16 & $\begin{array}{l}\text { Diploma from } \\
\text { University of } \\
\text { Applied Sciences }\end{array}$ & 729 & & & & \\
\hline 17 & & & & & & \\
\hline 18 & $\begin{array}{l}\text { University } \\
\text { graduate }\end{array}$ & 841 & $\begin{array}{l}\text { University level } \\
\text { or equivalent } \\
\text { (e.g. university } \\
\text { of applied } \\
\text { sciences) }\end{array}$ & 76 & University ( $4 / 5$ years) & 66 \\
\hline 19 & & & & & & \\
\hline 20 & & & Doctoral degree & - & & \\
\hline 21 & & & & & & \\
\hline
\end{tabular}


Supplementary Table 1 (continued).

\begin{tabular}{|c|c|c|c|c|c|c|}
\hline $\begin{array}{l}\text { N of education } \\
\text { years } \\
\text { (harmonized) }\end{array}$ & $\begin{array}{l}\text { Korean Twin- } \\
\text { Family Register }\end{array}$ & n & $\begin{array}{l}\text { Minnesota Twin } \\
\text { Registry }^{1}\end{array}$ & $\mathbf{n}$ & $\begin{array}{l}\text { Norwegian } \\
\text { Twin Registry }\end{array}$ & n \\
\hline 0 & Did not go to school & - & & & & \\
\hline 1 & & & & & & \\
\hline 2 & & & & & & \\
\hline 3 & $\begin{array}{l}\text { Dropped out of } \\
\text { Elementary School }\end{array}$ & 2 & 3 years & 1 & & \\
\hline 4 & & & 4 years & 1 & & \\
\hline 5 & & & 5 years & - & & \\
\hline 6 & $\begin{array}{l}\text { Graduated } \\
\text { Elementary School } \\
\text { or dropped out of } \\
\text { Middle School }\end{array}$ & 15 & 6 years & 1 & & \\
\hline 7 & & & 7 years & 2 & & \\
\hline 8 & & & 8 years & 6 & & \\
\hline 9 & $\begin{array}{l}\text { Graduated Middle } \\
\text { School or dropped } \\
\text { out of High School }\end{array}$ & 27 & 9 years & 18 & $\begin{array}{l}\text { Compulsory } \\
\text { School }\end{array}$ & 808 \\
\hline 10 & & & 10 years & 24 & & \\
\hline 11 & & & 11 years & 51 & $\begin{array}{l}\text { Secondary } \\
\text { School, low level }\end{array}$ & 1,098 \\
\hline 12 & $\begin{array}{l}\text { Graduated High } \\
\text { School }\end{array}$ & 186 & 12 years & 1,431 & & \\
\hline 13 & $\begin{array}{l}\text { Graduated } \\
\text { Community College }\end{array}$ & 62 & 13 years & 480 & & \\
\hline 14 & $\begin{array}{l}\text { Dropped out of } \\
\text { University }\end{array}$ & 24 & 14 years & 540 & $\begin{array}{l}\text { Secondary } \\
\text { School, high } \\
\text { level }\end{array}$ & 240 \\
\hline 15 & & & 15 years & 205 & & \\
\hline 16 & & & 16 years & 883 & & \\
\hline 17 & & & 17 years & 220 & & \\
\hline 18 & $\begin{array}{l}\text { Graduated } \\
\text { University }\end{array}$ & 265 & 18 years & 175 & University & 408 \\
\hline 19 & & & 19 years & 89 & & \\
\hline 20 & $\begin{array}{l}\text { Graduate School or } \\
\text { more }\end{array}$ & 67 & 20 years & 58 & & \\
\hline 21 & & & 21 years & 55 & & \\
\hline
\end{tabular}

${ }^{1}$ Education reported as exact number of years; $n$, number of twin individuals 